\title{
Топологии резонаторов волоконных лазеров с синхронизацией мод излучения: возможности и перспективы
}

\author{
$\underline{\text { Б.Н. Нюшков }}^{1-3, *}$, С.М. Кобцев ${ }^{1}$, А.В. Иваненко ${ }^{1}$ \\ ${ }^{1}$ Новосибирский государственный университет \\ ${ }^{2}$ Институт лазерной физики СО РАН \\ ${ }^{3}$ Новосибирский государственный технический университет \\ *E-mail: nyushkov@laser.nsc.ru
}

DOI:10.31868/RFL2018.141

В последние годы бурно развиваются волоконные технологии, позволяющие относительно просто конфигурировать различные схемы резонаторов волоконных лазеров, в том числе те, которые ранее невозможно было реализовать с помощью не волоконных компонентов. В связи с этим актуальна разработка физических основ короткоимпульсных волоконных источников излучения с резонаторами на основе новых топологий, так как ранее эмпирически было выявлено, что топологические особенности резонаторов этих лазеров в существенной степени влияют на ключевые свойства лазерной генерации - характеристики генерируемых импульсов, стабильность генерации, чувствительность её параметров к воздействию внешних факторов.

В докладе представлен обзор современных базовых топологий резонаторов волоконных лазеров с синхронизацией мод излучения, включающий новейшие топологии, разработанные авторами данного доклада. Рассмотрены схемы резонаторов с нелинейными петлевыми зеркалами (так называемые “резонаторы в виде восьмёрки”), линейно-кольцевые схемы, гамма-, тета-схемы, каплеобразные схемы и другие. Показаны особенности управления нелинейными, дисперсионными, поляризационными и спектральными свойствами внутрирезонаторной среды. Дан анализ роли топологии резонатора в комбинированном влиянии на свойства лазерной генерации, как самой топологии резонатора, так и физических свойств компонентов, формирующих топологию резонатора. Детально рассмотрены топологии резонаторов волоконных лазеров, обеспечивающих рекордные параметры излучения. 